\title{
Initiating and Growing an Axon
}

\author{
F. Polleux and William Snider \\ Neuroscience Center, University of North Carolina-Chapel Hill, Chapel Hill, North Carolina 27599-7250 \\ Correspondence: polleux@med.unc.edu
}

The ability of neurons to form a single axon and multiple dendrites underlies the directional flow of information transfer in the central nervous system. Dendrites and axons are molecularly and functionally distinct domains. Dendrites integrate synaptic inputs, triggering the generation of action potentials at the level of the soma. Action potentials then propagate along the axon, which makes presynaptic contacts onto target cells. This article reviews what is known about the cellular and molecular mechanisms underlying the ability of neurons to initiate and extend a single axon during development. Remarkably, neurons can polarize to form a single axon, multiple dendrites, and later establish functional synaptic contacts in reductionist in vitro conditions. This approach became, and remains, the dominant model to study axon initiation and growth and has yielded the identification of many molecules that regulate axon formation in vitro (Dotti et al. 1988). At present, only a few of the genes identified using in vitro approaches have been shown to be required for axon initiation and outgrowth in vivo. In vitro, axon initiation and elongation are largely intrinsic properties of neurons that are established in the absence of relevant extracellular cues. However, the importance of extracellular cues to axon initiation and outgrowth in vivo is emerging as a major theme in neural development (Barnes and Polleux 2009). In this article, we focus our attention on the extracellular cues and signaling pathways required in vivo for axon initiation and axon extension.

\section{AXON INITIATION IN VITRO VERSUS IN VIVO}

\section{Axon Initiation In Vitro}

$\mathrm{H}$ istorically, the advent of in vitro dissociated neuronal cultures provided an experimental template for improving our understanding of the cell biology of neuronal polarity, including the specification of the molecular identity of axon and dendrites (Goslin and Banker 1989; Craig and Banker 1994). Careful analysis of these cultures led to the observation that cultured hippocampal neurons transition through several stages: from freshly plated stage-1 cells bearing immature neurites to stage -5 cells that show mature axons, dendrites, dendritic spines, and functional synapses (Dotti et al. 1988; Craig and Banker 1994) (Fig. 1A). It should be noted that in the classical E18 rat hippocampal cultures, most plated cells are polarized postmitotic neurons before dissociation. It is therefore important to keep in mind that, in this in vitro model, molecular manipulations act on previously polarized neurons that may retain

Editors: Marc Tessier-Lavigne and Alex L. Kolodkin

Additional Perspectives on Neuronal Guidance available at www.cshperspectives.org

Copyright (C) 2010 Cold Spring Harbor Laboratory Press; all rights reserved; doi: 10.1101/cshperspect.a001925

Cite this article as Cold Spring Harb Perspect Biol 2010;2:a001925 
F. Polleux and W. Snider

A

Polarization of cortical neurons in vitro
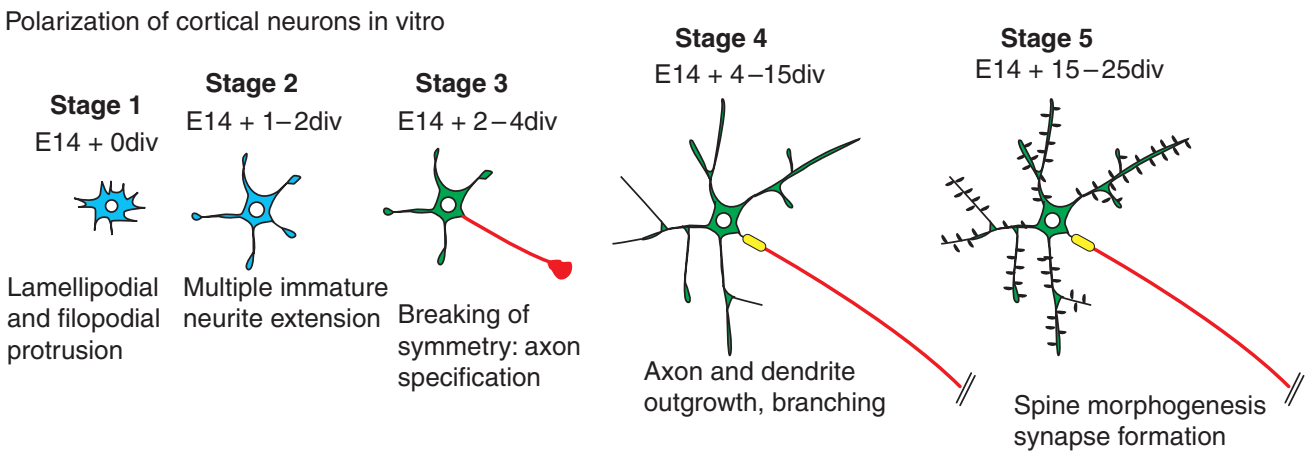

B Polarization of cortical neurons in vivo

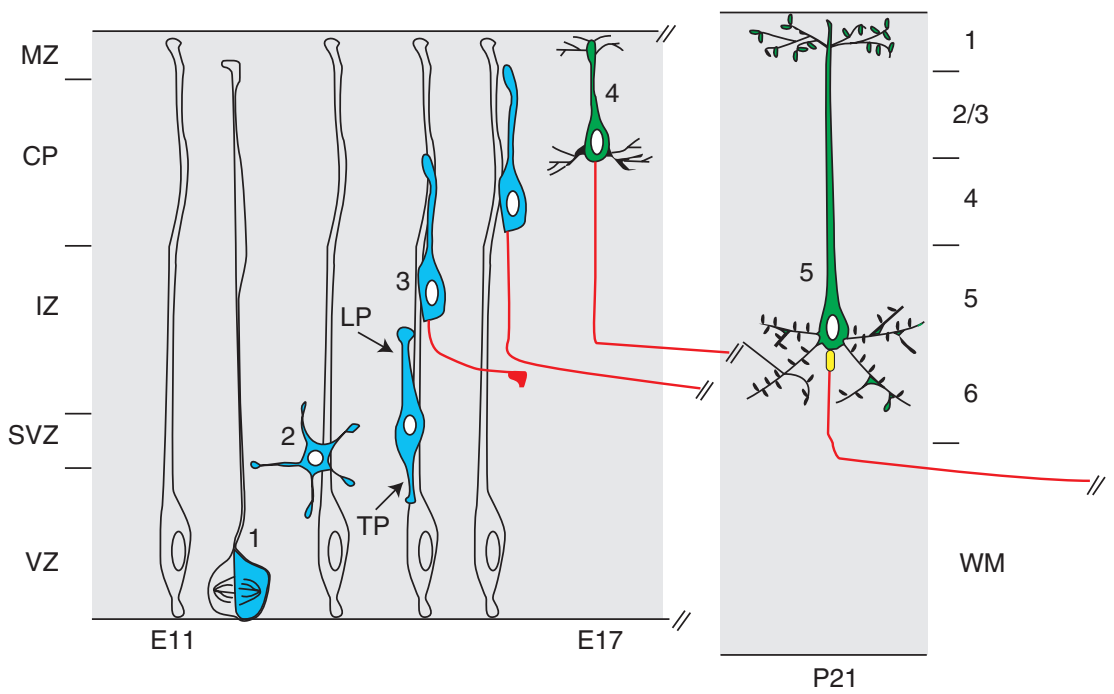

Figure 1. Parallels between neuronal polarization in vitro and in vivo. Comparison of the sequence of events leading to the polarization of cortical pyramidal neurons in vivo and in vitro. $(A)$ In dissociated cultures, postmitotic cortical neurons display specific transitions as classically described for hippocampal neurons by Dotti and Banker (1988). At stage 1, immature postmitotic neurons display intense lamellipodial and filopodial protrusive activity, which leads to the emergence of multiple immature neurites, stage 2. Stage 3 represents a critical step when neuronal symmetry breaks and a single neurite grows rapidly to become the axon (purple), whereas other neurites acquire dendritic identity. Stage 4 is characterized by rapid axon and dendritic outgrowth. Finally, stage 5 neurons are terminally differentiated pyramidal neurons harboring dendritic spines and the AIS. (B) The axon-dendrite polarity of pyramidal neurons is derived from the polarized emergence of the trailing (TP) and leading processes (LP), respectively. In vivo, pyramidal neurons acquire other key features of their terminal polarity, such as the axon initiation segment (AIS; yellow cartridge) and dendritic spines (gray protrusions) during the first postnatal weeks of development.

some aspects of their initial polarization. This can be critical for interpreting these experimental results. Recent advances in techniques such as in utero or ex utero cortical electroporation (Saito and Nakatsuji 2001; Tabata and Nakajima 2001; Hatanaka and Murakami 2002; Hand et al. 2005), provide a paradigm for (a) manipulating gene expression in progenitors (i.e., before neuronal polarization occurs on cell-cycle exit), and for (b) visualizing the earliest stages of neuronal polarization in a contextual cellular and molecular environment (i.e., in organotypic slices or intact embryonic brain) (Hand et al. 2005; Barnes et al. 2007; Calderon de Anda et al. 2008). 
Axon Initiation In Vivo

Neuronal polarization can be divided into several specific steps in vivo. On cell-cycle exit, mammalian neurons usually migrate over a long distance before reaching their final destination. In vivo, most neurons undergo axon-dendrite polarization during migration. Although migrating, neocortical pyramidal neurons form a leading process and a trailing process, each becoming the axon or the dendrite (Fig. 1B). Careful examination of the morphological transition between neural progenitors and postmitotic neurons reveals that neurons can inherit their axon and dendrite polarity directly from the apico-basal polarity of their progenitors. This is the case for retinal ganglion cells and bipolar cells in the developing vertebrate retina (Hinds and Hinds 1978; Morgan et al. 2006; Zolessi et al. 2006; reviewed in Barnes and Polleux 2009). In other neuronal subpopulations undergoing long-range migration, neuronal morphogenesis undergoes extensive stereotypical changes, leading to polarized outgrowth of their axon and dendrites. This is the case for cerebellar granule neurons (CGN) as well as cortical and hippocampal pyramidal neurons (PN), two of the best-studied models of neuronal polarization (Rakic 1971; Rakic 1972; Shoukimas and Hinds 1978; Gao and Hatten 1993; Komuro et al. 2001; Hatanaka and Murakami 2002; Noctor et al. 2004). Both CGN and PN acquire their axon-dendrite polarity from the polarized emergence during migration of their trailing and leading processes, respectively (Fig. 1B). Therefore, in these two neuronal cell types, an important functional relationship exists between the molecular mechanisms underlying polarized migration and the final axon-dendrite polarity.

As we discuss later, an emerging concept from recent work primarily in Caenorhabditis elegans suggests that in vivo, the "symmetrybreaking" events that lead to the emergence of the dendrite and the axon require the ability of postmitotic neurons to sense gradients of extracellular cues leading to the asymmetric activation of signaling pathways underlying the emergence of the axon. In this article, we provide a synthetic model of the molecular mechanisms underlying axon specification and axon growth in vitro and in vivo.

\section{DISTINCTION BETWEEN CUES REGULATING AXON SPECIFICATION VERSUS AXON GROWTH}

As mentioned previously, most studies published over the past two decades in this field have been performed using in vitro approaches. An important paradigm for confirming the regulatory role of a gene in neuronal polarity is to show that down-regulation of its expression, using shRNA technology or gene knockout technology, is required for axon formation. These experiments are typically performed using axon-specific markers and measurement of neurite length, because the axon usually grows five to 10 times faster than do neurites becoming dendrites. However, this type of evidence may not be sufficient to distinguish unambiguously an effector of axon specification from a molecule that is simply required for axon growth (Jiang et al. 2005). Conversely, showing that overexpression or overactivation of a candidate molecule leads to the emergence of multiple neurites displaying the molecular identity of an axon is generally interpreted to suggest that this molecule is sufficient to confer axon identity. However, this approach is limited because it relies on overexpression, which can be complicated by abnormal activation of a pathway normally not involved in axon specification or neuronal polarity. Given these technical issues, a more biologically relevant validation should include the test of the requirement of a candidate gene for neuronal polarity in vivo, or ex vivo, using gene knockout or shRNA-mediated knockdown technologies (Barnes et al. 2007).

\section{LOCAL PROTEIN TRANSLATION AND \\ DEGRADATION REGULATES AXON SPECIFICATION AND AXON GROWTH}

\section{Local Protein Degradation and Axon} Specification

Spatial regulation of protein expression by selective degradation has been shown in several 
contexts during neuronal development, including: axonal pruning (Watts et al. 2004); various aspects of axon guidance (Campbell and Holt 2001; DiAntonio et al. 2001; Bloom et al. 2007; Lewcock et al. 2007); synapse formation (DiAntonio et al. 2001; Nakata et al. 2005); synapse maintenance (DiAntonio et al. 2001; Aravamudan and Broadie 2003; Ehlers 2003; Speese et al. 2003); and synapse elimination (Ding et al. 2007) (reviewed in DiAntonio and Hicke 2004). Acute treatment with the proteosome inhibitor lactacystin blocks axogenesis in dorsal root ganglion cells (Klimaschewski et al. 2006). The protein kinase AKT is critical for neuronal polarity (see the following) and appears to undergo selective degradation (Yan et al. 2006), which selectively targets the inactive pool of AKT in neurites, resulting in a net enrichment of activated AKT in a single process becoming the axon. This phenomenon is consistent with the negative feedback signal model proposed by Kaibuchi and colleagues (Arimura and Kaibuchi 2007) to explain specification of a single axon during neuronal polarization. Schwamborn et al. recently showed that the small GTPase Raplb is regulated by a similar scheme because the active form of Raplb is spared from degradation and ultimately enriched in the axon (Schwamborn et al. 2007b). Additional work has shown that an interaction between Smurf2 and the polarity scaffold PAR3 must exist for proper neuron polarization (Schwamborn et al. 2007a). More complete understanding of this mechanism will require identification of both upstream regulatory signals responsible for its spatially limited activity and the cohort of proteins targeted for degradation in the nascent axon and dendrites.

\section{Local Protein Translation and Neuronal Polarization}

Another potential mechanism that could locally regulate proteins involved in axon specification or axon growth is local translation. The presence of mRNA and the translation machinery in developing axon and dendrites has been wellestablished (Job and Eberwine 2001), and their role in local protein synthesis is starting to emerge as an important molecular mechanism underlying synaptic plasticity (Sutton and Schuman 2006) and axon guidance (Lin and Holt 2008). However, the functional importance of local protein synthesis in axon specification and axon growth is still debated (Hengst and Jaffrey 2007). A recent study, using compartmentalized application of axon growth-stimulating cues only to axons, shows that intra-axonal protein translation is required for stimulated, but not basal, axon outgrowth (Hengst et al. 2009). Interestingly, the authors found that local translation of Par3 mRNA is triggered following both NGF or Netrin-1 application (Hengst et al. 2009). The definition of the repertoire of mRNA undergoing local translation, and the characterization of the functional importance in vitro and in vivo of these locally translated mRNAs, will undoubtedly improve our understanding of the molecular mechanisms underlying axon elongation.

\section{ROLE OF CYTOSKELETAL DYNAMICS IN AXON INITIATION AND GROWTH}

Cytoskeletal Dynamics and Axon Initiation

Appropriate regulation of the actin and microtubule cytoskeleton is critical for neuronal polarization and has been the focus of numerous studies. Experiments using the actin-destabilizing agents lactrunculin B and cytochalasin $\mathrm{D}$ indicate that remodeling of the actin-based cytoskeleton is an important regulatory step in axon formation (Bradke and Dotti 1999). Specifically, actin-depolymerization localized to a single neurite in unpolarized stage 2 hippocampal neurons is sufficient to confer axonal identity. For more details, we refer to Gertler (2010).

Microtubule Dynamics and Axon Elongation

APC (Adenomatous polyposis coli) is a wellestablished effector of GSK-3 that is enriched in the neurite that will become the axon early in neuronal polarization (Shi et al. 2004). Most cell biological evidence suggests that APC enhances microtubule stability and that APC can bind microtubule plus ends via its EB1 binding domain (Aoki and Taketo 2007). 
Phosphorylation of APC by GSK-3 $\beta$ reduces its ability to bind the plus ends of microtubules, and inhibition of GSK-3 $\beta$ leads to an accumulation of APC in multiple neurites (Shi et al. 2004). Expression of truncated forms of APC is sufficient to inhibit axon formation and elongation (Shi et al. 2004; Zhou et al. 2004; Purro et al. 2008). Recent work suggests that the APC/GSK-3 dyad regulates targeting of another polarity protein PAR3 (Shi et al. 2004; Zhou et al. 2004). Further, growth factor-triggered inactivation of GSK-3 $\beta$ by PI3K signaling acts through APC to control axon elongation (Zhou et al. 2004). Two other GSK-3 targets, the microtubule associated proteins (MAPs) MAP1b (Gonzalez-Billault et al. 2004) and Tau (Sperber et al. 1995), display reduced microtubule binding when phosphorylated by GSK-3. These results emphasize that the microtubule cytoskeleton is a major endpoint for polarity regulators. Interestingly, PTEN was also recently identified as a GSK-3 $\beta$ substrate (Maccario et al. 2007), and this may define a negative feedback loop for AKT signaling following activation via stabilization of PTEN.

\section{MAJOR SIGNALING PATHWAYS INVOLVED IN AXON INITIATION AND AXON GROWTH}

LKB1, SAD-A/B, and MARKs: The Mammalian Orthologs of Par4 and Par1

A pioneering genetic screen performed by Kemphues and colleagues in the late 1980s identified six Par genes encoding distinct protein families that play critical roles in epithelial cell polarity during development and metastasis (Kemphues et al. 1988; Goldstein and Macara 2007). Par4 (also known as the tumor-suppressor LKB1 or STK11) translocates from the nucleus and is activated by hetero-dimerization with one of two related pseudokinases known as Strad $\alpha$ and $\beta$ (Dorfman and Macara 2008). In addition to binding Strad, LKB1 function in neuronal polarity requires its phosphorylation at S431, a target of both protein kinase $\mathrm{A}$ and the p90RSK kinase (Collins et al. 2000; Sapkota et al. 2001). This phosphorylation event can be triggered by extracellular cues such as BDNF (brain derived neurotrophic factor) (Shelly et al. 2007) (Fig. 2). Future investigations will identify the relevant extracellular cues and the corresponding signaling pathways that trigger phosphorylation of LKB1 in position S431, thereby specifying the axon in developing cortical pyramidal neurons in vivo.

Once LKB1 is activated by binding to its necessary coactivator Strad, and S431-phosphorylation occurs (only in the neurite becoming the axon), LKB1 phosphorylates SAD-A/B kinases. In addition, LBK1 probably also phosphorylates microtubule affinity-regulated kinases, MARK1-4 (Matenia and Mandelkow 2009), which are required in part for axon specification because they phosphorylate microtubule-associated proteins such as Tau. On the basis of SAD kinase function in presynaptic vesicular clustering observed in C. elegans (Crump et al. 2001), we hypothesize that SAD-A/B kinases specify axon identity by directing presynaptic vesicular trafficking in the neurite becoming the axon. Most importantly, genetic deletion of LKB1 in cortical pyramidal neurons prevents axon formation, whereas overexpression of LKB1 and its coactivator Strad in neural progenitors or LKB1 alone in postmitotic cells is sufficient to lead to the formation of multiple axons (Asada et al. 2007; Barnes et al. 2007; Shelly et al. 2007).

LKB1 also phosphorylates and activates a family of 13 protein kinases related to the C. elegans PAR1 protein (Lizcano et al. 2004). To date, three of these have been implicated in regulating axon formation: $\mathrm{SAD}-\mathrm{A}$ and $\mathrm{SAD}-\mathrm{B}$ kinases, and also MARK-2 (microtubule affinity regulating kinase-2; also called Parlb). RNAi knockdown of SAD kinases partially abrogates the ability of LKB1 overactivation to induce the formation of multiple axons in cortical neurons, indicating that LKB1's function in promoting axogenesis largely derives from activation of SAD-A/B kinases (Barnes et al. 2007). Double knockout mice for SAD-A and $\mathrm{SAD}-\mathrm{B}$ results in neurons that cannot form axons in vivo (Kishi et al. 2005). SAD and MARK kinases target several MAPs, including MAP2, MAP4, and Tau, by phosphorylating three $\mathrm{K}-\mathrm{X}-\mathrm{G}-\mathrm{S}$ motifs within each protein, reducing 
F. Polleux and W. Snider

A

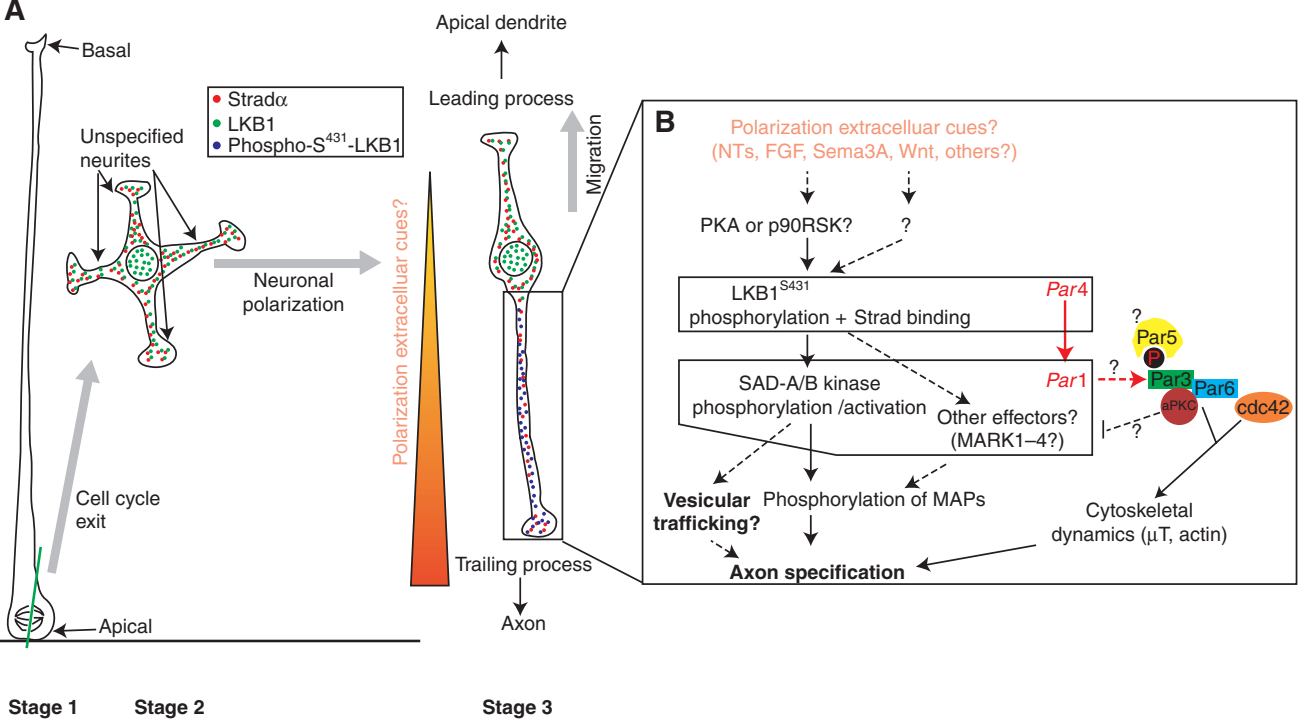

Figure 2. Molecular mechanisms underlying cortical neuron polarization in vivo. $(A)$ On asymmetric cell division of radial glial progenitors (Stage 1), early unpolarized postmitotic neurons show a transient phase of nondirected neurite outgrowth in the subventricular zone (Stage 2) before adopting a bipolar morphology in the intermediate zone, where they engage radial migration with a leading process directed toward the pial surface and a trailing process directed toward the ventricle. $(B)$ In vivo, the trailing process is specified to become the axon in response to putative extracellular cues that preferentially induce phosphorylation of LKB1 on Serine 431 (Barnes et al. 2007; Shelly et al. 2007). This event might be mediated in part by cues providing chemotactic attraction of radially migrating neurons toward the cortical plate such as Sema3A or any other extracellular cues neurotrophins (NTs) such as BDNF/NT4/NT3, Wnt, FGFs (see text for details), or other cues that can activate cAMP-dependent protein kinase (PKA) or p90 RSK (RSK1-3), which can phosphorylate LKB1 at S431 (Sapkota et al. 2001). One cannot exclude the possibility that another uncharacterized serine/threonine protein kinase can phosphorylate Serine 431 in vivo and play a role in neuronal polarization. Once LKB1 is activated by binding to its necessary co-activator Strad ( $\alpha$ or $\beta$ ) and S431-phosphorylation (which occurs only in the neurite becoming the axon), LKB1 phosphorylates SAD-A/ B kinases (and likely Microtubule Affinity-Regulated Kinases, MARK1-4), which are required for axon specification in part by phosphorylating microtubule-associated proteins such as Tau. Based on the function of SAD-kinases in presynaptic vesicular clustering in Caenorhabditis elegans (Crump et al. 2001), we hypothesize that SAD-A/B kinases might also specify axon identity by directing vesicular trafficking in the neurite becoming the axon. Based on evidence obtained in Drosophila melanogaster, Parl can phosphorylate Par3 on two serine residues that constitute binding sites for the 14-3-3 protein Par5, an event that controls its localization during $D$. melanogaster oocyte polarity. At present, this is the only potential link between the Par3/Par6/aPKC complex and Par4/Par1 dyad during cell polarization. Modified from Barnes et al. 2008. The boxes indicate the genes for which in vivo evidence shows a requirement for axon specification.

their microtubule binding affinity and thus destabilizes microtubules (Illenberger et al. 1996; Drewes et al. 1997; reviewed in Matenia and Mandelkow 2009). Little is known about SAD kinase regulation. However, a recent study implicates the tuberous sclerosis complex (TSC) genes $\mathrm{TSC} 1 / 2$ in regulating SAD protein abundance (Choi et al. 2008). The microtubule regulatory scheme is the same for the four members of MARK kinase family, but to date only MARK2 has been implicated in the regulation of neuronal polarity (Biernat et al. 2002; Chen et al. 2006).

\section{PAR3-PAR6-aPKC}

The core components of the other major proteins in the polarity complex identified in 
C. elegans are the scaffolding proteins PAR-3 and PAR-6. Many binding partners for this protein complex have been implicated in regulating the polarity of epithelial cells. Neuroepithelial radial glia target the PAR3/6 complex in their apical domain along the ventricular wall (Manabe et al. 2002; Costa et al. 2008). Proteins reported to exist in a complex with PAR3/ 6 include atypical forms of protein kinase $\mathrm{C}$ (aPKC: PKC $\lambda$ and $\zeta$ ) (Joberty et al. 2000; Lin et al. 2000; Qiu et al. 2000), the small GTPase cdc42 (Joberty et al. 2000; Lin et al. 2000; Qiu et al. 2000), the kinesin motor protein KIF3A (Nishimura et al. 2004), the guanine exchange factor Tiam1/STEF (Chen and Macara 2005; Nishimura et al. 2005), the lipid and protein phosphatase PTEN (von Stein et al. 2005; Feng et al. 2008), the GTPase activating protein (GAP) p190RhoGAP (Zhang and Macara 2008), the tumor suppressor lethal giant larvae (lgl) (Plant et al.2003), the scaffold protein inscuteable (Schober et al. 1999), the ubiquitin ligases Smurf1 (Ozdamar et al. 2005) and Smurf2 (Schwamborn et al. 2007b), and the transforming growth factor receptor 1 (TGFßR1) (Ozdamar et al.2005). Each of these proteins has also been implicated in controlling polarity in nonneuronal cells as part of the PAR3 / 6 complex.

We consider the potential function of some of these PAR3/6 interacting proteins ( $\mathrm{Lgl}$, Inscuteable, and Smurf1/2) later in this review in the context of progenitor polarity and protein stability, respectively. PAR3/6 are enriched in the nascent axon in stage 3 hippocampal neurons, and overexpression of wild-type and truncated forms of either PAR3 or PAR6 perturb the formation of a single axonal process in hippocampal neurons (Shi et al. 2003). However, in Drosophila, orthologs of PAR3 (bazooka), PAR6, or aPKC do not appear to be required for proper axon-dendrite specification (Rolls and Doe 2004). This could mean that PAR3/6 have acquired a function in neuronal polarity late in the evolution of the vertebrate radiation. Further, there is so far no genetic loss-offunction evidence in vertebrates (especially in mammals) demonstrating that Par3 and Par6 are required for axon specification. This evidence is clearly more challenging to obtain in mammals than in Drosophila because of potential genetic redundancy: There are four Par6 genes and two Par3-like genes in mammalian genomes (Goldstein and Macara 2007; Barnes et al. 2008).

\section{Ras- and Rho-Family of Small GTPases}

Small GTPases are critical regulators of cytoskeletal and membrane dynamics underlying cell motility, cell polarity, and cell growth. Not surprisingly, both Ras- and Rho-family small GTPases have been shown to be involved in axon specification and axon growth. We refer the reader to Hall and Lalli (2010) for a comprehensive review of the roles played by small GTPases in the regulation of neuronal morphology.

\section{PI3-Kinase Signaling and Axon Specification}

The phosphatidylinositol-3 kinase (PI3K) family regulates diverse biological functions. These include cell polarity, cell motility, and chemotaxis, as well as neuronal migration and polarization; however, these observations are drawn almost exclusively from the use of pharmacological inhibitors such as Wortmanin or LY294002 (Polleux et al. 2002; Shi et al. 2003; Jossin and Goffinet 2007; Zhou et al. 2007). The best characterized class Ia PI3-kinase (PI3KcIa) is involved in the formation of phosphatidylinositol $(3,4,5)$-triphosphate (PIP3), and it lies downstream of Ras and upstream of protein kinase $\mathrm{B}$ (or AKT) during signal transduction. Work from several groups implicates PI3K in axon specification based on the fact that pharmacologic inhibition of PI3K activity using LY294002 or Wortmannin prevents axon formation (Shi et al. 2003; Menager et al. 2004; Jiang et al. 2005; Yoshimura et al. 2006). However, these data have to be interpreted carefully because these inhibitors are not class-specific. They inhibit the three main classes of PI3K (Stack and Emr 1994), including phosphatidylinositol-3 kinase class III (PI3Kc3, also called Vps34) that produces exclusively phosphatidylinositol-3 monophosphate (PI(3)P) and regulates endocytosis, vesicular trafficking, trimeric 
F. Polleux and W. Snider

G-protein signaling, and the mTOR (mammalian target of rapamycin) pathway. Using the pleckstrin homology $(\mathrm{PH})$ domain of AKT fused to GFP ( $\left.\mathrm{PH}_{\mathrm{AKT}}-\mathrm{GFP}\right)$ as a biosensor for PIP3 formation, Menager et al. (2004) have shown that PIP3 accumulates selectively within a single neurite following local application of laminin to a single neurite of stage 2 hippocampal neurons. Future work using genetic loss-of-function approaches will address when and where PI3K activation occurs in vivo during neuronal polarization, and also which class of $\mathrm{PI} 3 \mathrm{~K}$ is required (class 1,2 , or 3 ).

\section{PTEN}

PTEN (Phosphatase and Tensin homolog deleted on chromosome 10) is a lipid and protein phosphatase that acts in direct opposition to PI3K activity because PTEN dephosphorylates PIP3, generating PIP2 and thus limiting PIP3 signaling both spatially and temporally. Increasing levels of PTEN expression leads to a loss of axon formation (Shi et al. 2003; Jiang et al. 2005), whereas reduction of PTEN expression via RNAi-mediated knockdown leads to a multiple axon phenotype (Jiang et al. 2005). This effect is consistent with the gain-of-function mutation of PI3K described previously and highlights the critical need for maintaining the delicate balance of phospholipid composition at the membrane to ensure proper neuronal polarization and axon formation. PTEN, remarkably, via regulation of the mTOR pathway, has a strong function in suppressing injuryinduced axon growth in CNS neurons (Park et al. 2008).

\section{AKT/Protein Kinase B}

Several proteins are recruited via their PIP3specific $\mathrm{PH}$ domains to membrane sites created by PI3KcIa activity. The protein kinase AKT, also called protein kinase $\mathrm{B}(\mathrm{PKB})$, undergoes such a translocation to the membrane via its $\mathrm{PH}$ domain. This step is required for AKT's activation by dual phosphorylation on T308 and S473 by the membrane-targeted protein kinases PKD1 and PKD2, respectively. This activated form of AKT is enriched in growth cones of polarized neurons (Shi et al. 2003). When a myristoylation site is added to recombinant AKT (myr-AKT), it is constitutively targeted to the membrane, independent of PI $3 \mathrm{~K}$, and therefore is constitutively active. When overexpressed in neurons, this form of AKT is sufficient for multiple axon formation (Yoshimura et al. 2006), consistent with a unified pathway in which AKT acts downstream of PI3K in regulating axon formation.

\section{GSK-3 and Axon Specification}

GSK-3 (glycogen synthase kinase 3) is a wellstudied serine/threonine protein kinase that functions in the regulation of multiple intracellular processes including pathways downstream of receptor tyrosine kinases and Wnt/Frizzled signaling. Two genes encoding GSK-3 ( $\alpha$ and $\beta$ ) in mammals perform essentially redundant functions. GSK-3 has the unusual property of being constitutively active, a state that is reversed following phosphorylation at Ser9 in GSK-3 $\beta$, or Ser 21 in GSK-3 $\alpha$, by multiple kinases including AKT, ILK, and atypical protein kinase C (aPKC) (Etienne-Manneville and Hall 2003). Recent in vitro work implicates GSK3 $\beta$ as a critical regulator of neuronal polarity. Experiments using several types of GSK-3 inhibitors indicate that GSK- $3 \alpha / \beta$ act as negative regulators of axon formation because they lead to formation of multiple axons (Jiang et al. 2005; Yoshimura et al. 2005).

A recent study suggests that the situation may be somewhat more complex in vivo. Using double knockin mice bearing single point mutations in GSK-3 $\beta^{\mathrm{S9A}}$ and GSK-3 $\alpha^{\mathrm{S} 21 \mathrm{~A}}$, Gartner et al. reported no obvious deficits in neuronal morphogenesis in vivo, or in vitro (Gartner et al. 2006). However, using inhibitors of GSK-3 $\alpha / \beta$ such as lithium chloride or, more specifically, SB-415286, SB-216763, and ARA014418, Gartner et al. (2006) were able to replicate the multiple axon phenotype obtained by others (Jiang et al. 2005; Garrido et al. 2007). These results indicate that although the exact role of Ser9/Ser21 phosphorylation in GSK-3 inactivation remains to be understood, 
or may involve an alternate site (Thornton et al. 2008), it is clear that the catalytic activity of GSK-3 is a critical regulator of neuronal polarity in these in vitro paradigms.

Several downstream targets of GSK-3 are potential effectors of neuronal polarity, and many involve regulation of the cytoskeleton. Collapsinresponse mediator protein-2 (CRMP-2) is one such microtubule-binding protein that is enriched in tip of the nascent axon and is regulated by GSK-3 $\beta$, such that phosphorylated CRMP-2 displays a decreased binding affinity for tubulin heterodimers (Inagaki et al. 2001; Yoshimura et al. 2005; reviewed in Arimura et al. 2004). As seen for other polarity regulators, overexpression of CRMP-2 is sufficient to induce the formation of multiple axons, and truncated forms of CRMP-2 can impair axon formation (Inagaki et al. 2001).

\section{GSK-3 and Axon Elongation}

A key issue for efficient axon elongation is regulation of microtubules polymerization. Although this question is only beginning to be addressed in primary neurons, there are some indications about kinases that may orchestrate this process. Abundant in vitro evidence suggests a potentially important role for GSK-3. GSK-3 has multiple substrates that have the potential to regulate tubulin polymerization and microtubule stability. These include the microtubule plus-end binding proteins APC and CLASP2, CRMP-2, which is localized to axon tips and may play a role in cargo delivery and tubulin polymerization, and the microtubule associated proteins MAP1B and tau (reviewed in Zhou and Snider 2006). Details of how these proteins function and how they are regulated by GSK-3 phosphorylation remain obscure. However, abundant in vitro evidence implicates GSK-3 as having an important role in axon elongation.

Virtually all studies indicate that low doses of GSK-3 inhibitors induce axon branching. This may be a counterpart to the elaboration of multiple axons in the hippocampal paradigm outline above. Normally, GSK-3 inhibition and APC plus-end binging are localized to the axon growth cone downstream of PI3K signaling (Eickholt et al. 2002; Zhou et al. 2004; Cosker et al. 2008). More general inhibition of GSK-3 may induce multiple foci along the axon capable of supporting efficient tubulin polymerization, thus resulting in branching. In DRG neurons, cGMP is an important mediator of axon branching, and a key cGMP dependent protein kinase (PrkG1) directly binds to and regulates GSK-3 activity (Zhao et al. 2009). There is a clear in vivo correlate to these observations, because elimination of PrkG1 strongly reduces the normal bifurcation of the central process of DRG neurons. Importantly, there appear to be other in vivo correlates of this regulation. Wnt 3 can induce branching of the central process of proprioceptive DRG neurons, and it seems reasonable that GSK-3 inhibition mediated via canonical Wnt signaling is a critical component of this branch induction (Krylova et al. 2002).

As noted previously, two GSK-3 family members, GSK- $3 \alpha$ and GSK-3 $\beta$, have largely redundant functions. Elimination of either family member alone has little effect on axon growth, either in vitro or in vivo (Kim et al. 2006; Kim et al. 2009). However, complete inhibition of GSK-3 activity via inhibitors or shRNA directed at both family members appears to block axon growth altogether in vitro (Shi et al. 2004; Kim et al. 2006; Garrido et al. 2007). Presumably, some baseline level of GSK-3 activity is required for efficient microtubule assembly. Floxed alleles for both GSK- $3 \alpha$ and GSK-3 $\beta$ have recently been generated (Kim et al. 2009), and therefore GSK-3 functions in axon growth in vivo should be defined shortly. GSK-3 regulation of axon growth may have important clinical significance because GSK-3 inhibition has produced modest, but statistically significant, improvement in rodent spinal cord injury models (Dill et al. 2008).

\section{RAF/MEK/ERK Regulation of Axon Growth}

It is logical to suppose that many of the principles associated with axon initiation are also operative in the setting of axon growth and extension toward target fields. In the case of RAS 
F. Polleux and W. Snider

and its downstream effector, the RAF/MEK/ ERK cascade, abundant in vitro evidence supports an important function in axon growth. Thus, many studies with the major pharmacological inhibitors PD98059 and U0126 show striking inhibition of axon growth induced by neurotrophins and other factors acting via receptor tyrosine kinases (see Zhou and Snider 2006, for a review). Further, both loss and gain of function studies in vitro suggested strong axon growth promoting functions for Ras, Raf, and ERK/MAPK (Markus et al. 2002). Indeed, ERK/MAPK appear well-positioned to regulate axon growth via its well-characterized regulation of a broad range of transcription factors, including SRF, and local regulation of the axonal cytoskeleton via phosphorylation of several microtubule-associated proteins. Perhaps surprisingly, evidence to date indicates a role for ERK/MAPK signaling in target field arborization but not in long-range axon extension. Thus, early ablation of the ERK/MAPK mediator SRF in DRG neurons using a Cre recombinase active in neural crest cells showed a striking ability of DRG neurons to extend long distances into the hindlimb during embryonic development (Wickramasinghe et al. 2008). However, axonal arborization into cutaneous target fields was abolished. These findings indicate that initial axon extension and also longrange growth can occur in the absence of SRF, but when axons encounter NGF ERK/MAPK SRF signaling, SRF is required for growth responses. More recent studies eliminating both ERK1 and ERK2 also show that long-range axon growth in both the PNS and CNS appears unimpeded in the absence of ERK in many classes of neurons (Samuels et al. 2008; Newbern and Snider, unpubl. observations).

\section{JNK Signaling and Axon Elongation}

Recent findings have revealed a critical role for c-Jun amino-terminal kinase (JNK) signaling, classically considered a degenerative signal and a stress-response signaling pathway, in the regulation of axonal outgrowth. Analysis of the effects of JNK deletion on axonal elongation in vivo has been complicated by the presence of three partially redundant JNK isoforms, and also by JNK's key role in cell death (Kuan et al. 1999; Sabapathy et al. 1999; Brecht et al. 2005). Nonetheless, deletion of a single isoform, JNK1, disrupts axon tract maintenance in vivo (Chang et al. 2003; Bjorkblom et al. 2005). The role of JNKs in axonal polarity and initiation is further supported by many cell culture studies showing that JNK inhibition attenuates neuritogenesis (Leppa et al. 1998; Waetzig and Herdegen 2003; Eom et al. 2005; Oliva et al. 2006; Newbern et al. 2007). Numerous lines of evidence suggest this pathway is also important for axonal extension (Leppa et al. 1998; Rosso et al. 2005; Xiao et al. 2006; Ciani and Salinas 2007; Eminel et al. 2008). JNKs show constitutively high activity within neurons and phosphorylate various cytoskeletal proteins involved in axon extension, including MAP1B, MAP2, tau, and SCG10, among others (Kyriakis and Avruch 1990; Otto et al. 2000; Neidhart et al. 2001; Tararuk et al. 2006; Yamauchi et al. 2006; Ciani and Salinas 2007). Axonal transport is modulated by $\mathrm{JNK}$, and it has been proposed that JNK triggers the release of cargoes, such as tubulin, from kinesin complexes (Stagi et al. 2006; Horiuchi et al. 2007). It is clear that the repertoire of JNK substrates is well-suited to mediate many aspects of axonal development.

\section{Transcription Regulators}

Transcription is a key aspect of axonal elongation, targeting, and regeneration after injury (Polleux et al. 2007). Surprisingly, despite intensive transcriptional profiling efforts, few transcriptional regulators of axon extension have been identified. One elegant mechanism has been defined involving the anaphase promoting complex (APC), which functions as an E3 ubiquitin ligase in the regulation of cyclins and other mediators of cell-cycle control. In postmitotic neurons, APC and its activator protein, Cdh1, stimulate degradation of the transcription factor SnoN (Konishi et al. 2004; Stegmuller et al. 2006). SnoN levels are also regulated by TGF- $\beta /$ SMAD-2 signaling (Stegmuller et al. 2008). Knockdown experiments in vivo show that reduction of Cdh1 enhances axon growth 
of cerebellar granule cells and, conversely, reduction of SnoN expression reduces granule cell axon growth. One important target of SnoN is the scaffolding protein $\mathrm{Cdcl}$, which controls JNK activity (Ikeuchi et al. 2009). Cell biological work in vitro, and also shRNA experiments in vivo, strongly point to SnoN as a key transcriptional regulator of axon growth during nervous system development. However, genetic loss-offunction mouse models will be needed to fully appreciate the requirement of this signaling pathway for axon elongation in these and other neuronal subtypes in vivo.

Other transcriptional regulators that have been documented to control axon extension include CREB and NFAT transcription complexes (Lonze et al. 2002; Graef et al. 2003). The role of the NFATc family is particularly striking in vivo. In mice lacking 3 NFATc family members, peripheral axon extension fails almost completely at early developmental stages. Further, longitudinal sensory axon tracts do not form in the spinal cord, and commissural neuron axons do not cross the midline near the floor plate. In vitro experiments reveal that both NGF and Netrin1-mediated responses are abolished (Graef et al. 2003). Importantly, the loss of NFATc family members can be mimicked by inhibiting Calcineurin, and it is important to note that NFATc subunits are controlled by both ERK/MAPK and GSK-3 phosphorylation (Crabtree and Olson 2002). To date, the role of NFATc family members has been studied only at the earliest stages of axon growth because of the lack of viability of the null mutants beyond mid-embryonic stages.

\section{EXTRACELLULAR CUES REGULATING NEURONAL POLARIZATION AND AXON INITIATION IN VIVO}

Netrin-1 and Wnt Control Axon Initiation in C. elegans

Is there any in vivo evidence for the role of extracellular cues in the specification of neuronal polarity? Important progress toward our understanding of the molecular and cellular mechanisms specifying axon initiation during neuronal polarization has been made in C. elegans (Quinn and Wadsworth 2008). This work has markedly enhanced our understanding of how extracellular cues instruct axon initiation in vivo. The neurons of the nematode have a stereotyped morphology, e.g., specific projections along the dorso-ventral and anteriorposterior body axes. Elegant experiments have identified an extracellular cue, UNC-6 (netrin), along with its receptor UNC-40 (DCC), as critical for orchestrating axon initiation in vivo (Adler et al. 2006). This work also identified downstream proteins in this pathway, including (mammalian orthologs are shown in parenthesis where established): AGE-1 (PI3K), DAF-18 (PTEN), UNC-34 (Enabled), CED-10 (Rac), UNC-115/ AbLIM, and MIG-10/Lamellipodin. The current model for the relationship of these genes to UNC-6 signaling involves DAF-18's limitation of AGE-1 activity following UNC-40 stimulation and the asymmetric recruitment of MIG-10 to the plasma membrane. This recruitment requires activated CED-10 (Rac) directly binding to MIG-10 (Quinn et al. 2008) and also the involvement of the PAK-like kinase Pak-1 (Adler et al. 2006). Another regulator thought to act in concert with MIG-10 to drive directed filopodial formation is the Enabled homolog, UNC-34 (Chang et al. 2006). SLT-1 (Slit) is another extracellular cue that likely acts through MIG-10 recruitment to control neuronal polarization (Chang et al. 2006).

Two other studies have identified the diffusible signal Wnt and its receptor as critical regulators of axon specification and neuronal polarity (Hilliard and Bargmann 2006; Prasad and Clark 2006). In addition to identifying loss-of-function for Lin-44 (Wnt) and its receptor Lin-17 (Frizzled) as being required for these processes, one of the screens also identified VPS-35, a component of retromer complex that regulates vesicular traffic and is required for proper Wnt secretion (Prasad and Clark 2006; Pan et al. 2008).

Careful live imaging experiments of Xenopus retinal ganglion cell polarization revealed that polarized axon outgrowth requires some unidentified extracellular cues present in the basal lamina (Zolessi et al. 2006). This work 
strongly suggests that: (a) the basal lamina contains important extracellular cues that play a role in the polarized emergence of the axon of RGC neurons and that (b) RGC neurons inherit the intrinsic apico-basal polarity of their progenitor, at least with regard to the Par3/aPKC components of the polarity complex.

\section{Laminin, BDNF, Sema3A, and Other Cues in Mammalian Neurons}

Several lines of evidence suggest that extracellular cues can direct the polarized emergence of the axon and dendrites both in vitro and in vivo. One paradigm involves dissociated cortical or hippocampal pyramidal neurons plated on striped substrates coated with two different cell adhesion molecules (Laminin and NgCAM, for example) (reviewed in Barnes and Polleux 2009). The first immature neurite of E18 hippocampal neurons that contacts the boundary between two stripes reproducibly becomes the axon (Esch et al. 1999). Using a similar approach, Shelly and colleagues showed that neurites of immature hippocampal neurons growing on a patterned substrate can detect the presence of BDNF, which plays an instructive role in axon specification because the first neurite contacting a BDNF stripe reproducibly becomes the axon (Shelly et al. 2007). The effect of BDNF on axon specification requires cAMP-dependent protein kinase (PKA) activation and phosphorylation of LKB1 in position 431 by PKA (Shelly et al. 2007), suggesting that LKB1 phosphorylation on S431 acts as a detector of a break in neuronal symmetry induced by extracellular cues such as BDNF in this in vitro context.

Using a slice overlay assay, Polleux et al. have shown that only a couple of hours after plating, the vast majority of cortical neurons displayed a single short axon directed ventrally toward the ventricle (Polleux et al. 1998), as is found in vivo (see Fig. 1). These authors went on to show that the class 3 secreted semaphorin, Sema3A, which is enriched in the most superficial part of the cortical wall (the top of the cortical plate) (see also Chen et al. 2008), plays a role in repulsing axon initiation ventrally toward the ventricle (Polleux et al. 1998). This work suggests that the polarized emergence of a single axon is controlled at least in part by extracellular cues expressed in a graded manner along the neuron's migratory path.

\section{EXTRACELLULAR CUES REGULATING AXON GROWTH}

Activity-dependent versus Activity-independent Axon Outgrowth

A central unresolved issue is whether or not neuronal activity is required for proper axon elongation in vivo. Careful in vivo analyses provide strong evidence suggesting that for specific neuronal subtypes, such as retinal ganglion cells (RGC), axon growth stimulated by various neurotrophic is normally remarkably slow, but profoundly potentiated by physiological levels of electrical activity, either spontaneously generated within explants or mimicked by multielectrode silicon chip stimulation (Goldberg et al. 2002). In vivo, elegant imaging studies have provided direct evidence for a negative relationship between the frequency of spontaneous calcium transients and the rate of axon outgrowth (Gomez et al. 1995; Gomez and Spitzer 1999). The relevance of these findings to other neuronal populations in various organisms will need to be explored before these findings can be generalized; however, modulation of neuronal activity is an attractive mechanism for regulating axon growth and targeting in vivo by tuning the response to extrinsic axon growthpromoting cues and axon guidance cues.

\section{Control of Axon Elongation by Neuronal Growth Factors}

Once axon specification occurs, the axonal process begins to grow at a rate approximately 10 times faster than the other processes. Although there is some intrinsic capability of a process to extend at a rapid rate, most experimental paradigms that have employed highly reduced conditions indicate that extracellular factors are required for the gene transcription and cytoskeletal assembly that underlies rapid axon extension (Lentz et al. 1999; Goldberg et al. 2002; Ozdinler and Macklis 2006). 
Numerous in vitro studies, mostly of the gain-of-function variety, show dramatic effects of several neuronal growth factors on neuronal classes bearing receptors for these molecules (reviewed in Chao 2003; Reichardt 2006). An early complication in interpreting such studies was the separation of survival versus growthpromoting effects. However, recently, there has been broad use of the manipulation of the Bcl-2 apoptosis pathway to address this issue. Neuronal survival can be maintained indefinitely in the absence of exogenous factors using overexpression of $\mathrm{Bcl}-2, \mathrm{Bcl}-\mathrm{X}$, or elimination of $\mathrm{Bax}$ (reviewed in Akhtar et al. 2004; Youle and Strasser 2008). Using this approach, multiple studies have now established robust axon-growth promoting effects of growth factors acting through receptor tyrosine kinases and cytokines (Lentz et al. 1999; Goldberg et al. 2002).

Despite these robust effects, the in vitro studies showing the ability of several factors to trigger growth have to be interpreted with caution. First, factors that show strong effects under reduced conditions in vitro may not be required in the rich in vivo environment. Axons are exposed to a myriad of diffusible and surface anchored growth-promoting molecules in vivo that may compensate for the loss of a specific factor. Second, the ability to trigger axon growth in a dish usually does not establish when and where these factors regulate axon growth along its trajectory in vivo. Robust growth promoting effects in vitro may be irrelevant to axon extension but may indicate, instead, that a factor is required for induction of collateral branching (Wang et al. 1999; Brose and Tessier-Lavigne 2000) or for induction of terminal branching near target cells (Hall et al. 2000; Krylova et al. 2002; Salinas and Zou 2008). Finally, if a rich mixture of surface molecules (e.g., Matrigel) is presented to the neuron, growth promoting effects of any specific factor may be difficult to detect, even when such molecules are known to be important for axon growth or targeting in vivo (Graef et al. 2003; Wickramasinghe et al. 2008).

Mouse genetic studies have provided accumulating evidence for in vivo roles for neurotrophins and GDNF family members. Interestingly, the earliest phases of PNS axon growth are clearly neurotrophin independent. Thus, BDNF and NT-3-sensitive trigeminal neurons extend toward their target fields in the periphery and are sensitive to both $\operatorname{TrkB}$ and TrkC deletion (O'Connor and Tessier-Lavigne 1999). GDNF family members may have a role in early phases of extension of sympathetic ganglion cell axons, but whether this generalizes to other PNS neurons is not yet certain (Honma et al. 2002; Kuruvilla et al. 2004; Luo et al. 2007). Later stages of axon growth along vessels appear to require NT-3 acting locally (Kuruvilla et al. 2004). Similarly, within the CNS, in vivo evidence does not support a role for neurotrophins or GDNF family members in the earliest stages of axon extension (Chao 2003). Gain of function studies show strong effects of neurotrophins on axon branching, but in only one case has a known role for a neurotrophin related to an axon trajectory been established (Ma et al. 2002).

Although the early phases of axon growth may be neurotrophin-independent, later stages of axon growth associated with growth of limbs also clearly require NT signaling (Patel et al. 2000; Tucker et al. 2001; Patel et al. 2003). Furthermore, it is now clearly established that NGF and NT-3 regulate target field innervation. In mice lacking NGF or TrkA, where neuronal survival is preserved by absence of BAX, NGFresponsive axons do not invade cutaneous target fields. Similarly, proprioceptive axons do not innervate muscle spindles in the absence of NT-3 or TrkC (Patel et al. 2003). Finally, in the setting where the ERK/MAPK effectors RAF kinase and SRF are absent, terminal axonal arborization, but not long range extension, is impaired at embryonic stages (Zhong et al. 2007; Wickramasinghe et al. 2008).

Within the CNS, studies of mice harboring null and conditional mutants for members of the neurotrophin or GDNF families have not shown significant effects on axon extension and targeting. An exception is the central projections of DRG neurons, where elimination of NT-3 in concert with elimination of BAX abrogates central branching of proprioceptive axons via regulation of the transcription factor ER81 (Patel et al. 2003). There are numerous other examples in the CNS where elimination 
of transcription factors affects axon guidance and targeting (Polleux et al. 2007), but whether these effects are controlled by growth factor signaling is still poorly understood. Finally, neutralizing IGF1 receptor signaling with direct antibody injections has shown failure of axon elongation and targeting of CST axons in the spinal cord (Ozdinler and Macklis 2006). This suggests that RTK signaling and pathways considered above may be important for growth and targeting of CNS axon tracts. However, for many CNS neurons, precise factors that regulate axon extension remain to be identified.

\section{CONCLUSION AND FUTURE DIRECTIONS}

Our knowledge of the intrinsic molecular mechanisms underlying the ability of neurons to polarize by extending a single axon and multiple dendrites has clearly improved over the past two decades (Craig and Banker, 1994; Arimura and Kaibuchi 2007). In contrast, our understanding of how these intrinsic signaling pathways are regulated by the action of extracellular cues during neuronal polarization in vivo is still fragmented (Barnes and Polleux 2009). Future work will clearly identify: (1) the extracellular cues and cellular mechanisms underlying axon and dendrite specification in mammalian CNS neurons in vivo; (2) how these extracellular cues regulate the spatial pattern of activation of specific signaling pathways during neuronal polarization; and (3) how axon growth is regulated in vivo during normal development and following injury.

\section{REFERENCES}

Adler CE, Fetter RD, Bargmann CI. 2006. UNC-6/Netrin induces neuronal asymmetry and defines the site of axon formation. Nat Neurosci 9: 511-518.

Akhtar RS, Ness JM, Roth KA. 2004. Bcl-2 family regulation of neuronal development and neurodegeneration. Biochim Biophys Acta 1644: 189-203.

Aoki K, Taketo MM. 2007. Adenomatous polyposis coli (APC): A multi-functional tumor suppressor gene. $J$ Cell Sci 120: 3327-3335.

Aravamudan B, Broadie K. 2003. Synaptic Drosophila $\mathrm{UNC}-13$ is regulated by antagonistic G-protein pathways via a proteasome-dependent degradation mechanism. J Neurobiol 54: 417-438.
Arimura N, Kaibuchi K. 2007. Neuronal polarity: From extracellular signals to intracellular mechanisms. Nat Rev Neurosci 8: 194-205.

Arimura N, Menager C, Fukata Y, Kaibuchi K. 2004. Role of CRMP-2 in neuronal polarity. J Neurobiol 58: 34-47.

Asada N, Sanada K, Fukada Y. 2007. LKB1 regulates neuronal migration and neuronal differentiation in the developing neocortex through centrosomal positioning. J Neurosci 27: 11769-11775.

Barnes AP, Polleux F. 2009. Establishment of axon-dendrite polarity in developing neurons. Annu Rev Neurosci 32: 347-381.

Barnes AP, Solecki D, Polleux F. 2008. New insights into the molecular mechanisms specifying neuronal polarity in vivo. Curr Opin Neurobiol 18: 44-52.

Barnes AP, Lilley BN, Pan YA, Plummer LJ, Powell AW, Raines AN, Sanes JR, Polleux F. 2007. LKB1 and SAD kinases define a pathway required for the polarization of cortical neurons. Cell 129: 549-563.

Biernat J, Wu YZ, Timm T, Zheng-Fischhofer Q, Mandelkow E, Meijer L, Mandelkow EM. 2002. Protein kinase MARK/PAR-1 is required for neurite outgrowth and establishment of neuronal polarity. Mol Biol Cell 13: 4013-4028.

Bjorkblom B, Ostman N, Hongisto V, Komarovski V, Filen J-J, Nyman TA, Kallunki T, Courtney MJ, Coffey ET. 2005. Constitutively active cytoplasmic c-Jun N-terminal kinase 1 Is a dominant regulator of dendritic architecture: role of microtubule-associated protein 2 as an effector. J Neurosci 25: 6350-6361.

Bloom AJ, Miller BR, Sanes JR, DiAntonio A. 2007. The requirement for Phrl in CNS axon tract formation reveals the corticostriatal boundary as a choice point for cortical axons. Genes Dev 21: 2593-2606.

Bradke F, Dotti CG. 1999. The role of local actin instability in axon formation. Science 283: 1931-1934.

Brecht S, Kirchhof R, Chromik A, Willesen M, Nicolaus T, Raivich G, Wessig J, Waetzig V, Goetz M, Claussen M et al. 2005. Specific pathophysiological functions of JNK isoforms in the brain. Eur J Neurosci 21: 363-377.

Brose K, Tessier-Lavigne M. 2000. Slit proteins: Key regulators of axon guidance, axonal branching, and cell migration. Curr Opin Neurobiol 10: 95-102.

Calderon de Anda F, Gartner A, Tsai LH, Dotti CG. 2008. Pyramidal neuron polarity axis is defined at the bipolar stage. J Cell Sci 121: 178-185.

Campbell DS, Holt CE. 2001. Chemotropic responses of retinal growth cones mediated by rapid local protein synthesis and degradation. Neuron 32: 1013-1026.

Chang C, Adler CE, Krause M, Clark SG, Gertler FB, TessierLavigne M, Bargmann CI. 2006. MIG-10/lamellipodin and AGE-1/PI3K promote axon guidance and outgrowth in response to slit and netrin. Curr Biol 16: 854-862.

Chang L, Jones Y, Ellisman MH, Goldstein LS, Karin M. 2003. JNK1 is required for maintenance of neuronal microtubules and controls phosphorylation of microtubule-associated proteins. Dev Cell 4: 521-533.

Chao MV. 2003. Neurotrophins and their receptors: A convergence point for many signalling pathways. Nat Rev Neurosci 4: 299-309. 
Chen X, Macara IG. 2005. Par-3 controls tight junction assembly through the Rac exchange factor Tiam1. Nat Cell Biol 7: 262-269.

Chen G, Sima J, Jin M, Wang KY, Xue XJ, Zheng W, Ding YQ, Yuan XB. 2008. Semaphorin-3A guides radial migration of cortical neurons during development. Nat Neurosci 11: $36-44$

Chen YM, Wang QJ, Hu HS, Yu PC, Zhu J, Drewes G, Piwnica-Worms H, Luo ZG. 2006. Microtubule affinity-regulating kinase 2 functions downstream of the PAR-3/PAR-6/atypical PKC complex in regulating hippocampal neuronal polarity. Proc Natl Acad Sci 103: 8534-8539.

Choi YJ, Di Nardo A, Kramvis I, Meikle L, Kwiatkowski DJ, Sahin M, He X. 2008. Tuberous sclerosis complex proteins control axon formation. Genes Dev 22: 2485-2495

Ciani L, Salinas PC. 2007. c-Jun N-terminal kinase (JNK) cooperates with Gsk $3 \beta$ to regulate Dishevelled-mediated microtubule stability. BMC Cell Biol 8: 27.

Collins SP, Reoma JL, Gamm DM, Uhler MD. 2000. LKB1, a novel serine/threonine protein kinase and potential tumour suppressor, is phosphorylated by cAMPdependent protein kinase (PKA) and prenylated in vivo. Biochem J 345 Pt 3: 673-680.

Cosker KE, Shadan S, van Diepen M, Morgan C, Li M, Allen-Baume V, Hobbs C, Doherty P, Cockcroft S, Eickholt BJ. 2008. Regulation of PI3K signalling by the phosphatidylinositol transfer protein PITP alpha during axonal extension in hippocampal neurons. J Cell Sci 121: 796-803.

Costa MR, Wen G, Lepier A, Schroeder T, Gotz M. 2008. Par-complex proteins promote proliferative progenitor divisions in the developing mouse cerebral cortex. Development 135: 11-22.

Crabtree GR, Olson EN. 2002. NFAT signaling: Choreographing the social lives of cells. Cell 109: S67-79.

Craig AM, Banker G. 1994. Neuronal polarity. Annu Rev Neurosci 17: 267-310.

Crump JG, Zhen M, Jin Y, Bargmann CI. 2001. The SAD-1 kinase regulates presynaptic vesicle clustering and axon termination. Neuron 29: 115-129.

DiAntonio A, Hicke L. 2004. Ubiquitin-dependent regulation of the synapse. Annu Rev Neurosci 27: 223-246.

DiAntonio A, Haghighi AP, Portman SL, Lee JD, Amaranto AM, Goodman CS. 2001. Ubiquitination-dependent mechanisms regulate synaptic growth and function. Nature 412: 449-452.

Dill J, Wang H, Zhou F, Li S. 2008. Inactivation of glycogen synthase kinase 3 promotes axonal growth and recovery in the CNS. J Neurosci 28: 8914-8928.

Ding M, Chao D, Wang G, Shen K. 2007. Spatial regulation of an E3 ubiquitin ligase directs selective synapse elimination. Science 317: 947-951.

Dorfman J, Macara IG. 2008. STRAD $\{\alpha\}$ regulates LKB1 localization by blocking access to importin- $\{\alpha\}$, and by association with Crm1 and Exportin-7. Mol Biol Cell 19: $1614-1626$.

Dotti CG, Sullivan CA, Banker GA. 1988. The establishment of polarity by hippocampal neurons in culture. J Neurosci 8: $1454-1468$.
Drewes G, Ebneth A, Preuss U, Mandelkow EM, Mandelkow E. 1997. MARK, a novel family of protein kinases that phosphorylate microtubule-associated proteins and trigger microtubule disruption. Cell 89: 297-308.

Ehlers MD. 2003. Activity level controls postsynaptic composition and signaling via the ubiquitin-proteasome system. Nat Neurosci 6: 231-242.

Eickholt BJ, Walsh FS, Doherty P. 2002. An inactive pool of GSK-3 at the leading edge of growth cones is implicated in Semaphorin 3A signaling. J Cell Biol 157: 211-217.

Eminel S, Roemer L, Waetzig V, Herdegen T. 2008. c-Jun Nterminal kinases trigger both degeneration and neurite outgrowth in primary hippocampal and cortical neurons. J Neurochem 104: 957-969.

Eom DS, Choi WS, Ji S, Cho JW, Oh YJ. 2005. Activation of c-Jun N-terminal kinase is required for neurite outgrowth of dopaminergic neuronal cells. Neuroreport 16: $823-828$.

Esch T, Lemmon V, Banker G. 1999. Local presentation of substrate molecules directs axon specification by cultured hippocampal neurons. J Neurosci 19: 6417-6426.

Etienne-Manneville S, Hall A. 2003. Cdc42 regulates GSK-3beta and adenomatous polyposis coli to control cell polarity. Nature 421: 753-756.

Feng W, Wu H, Chan LN, Zhang M. 2008. Par-3-mediated junctional localization of the lipid phosphatase PTEN is required for cell polarity establishment. J Biol Chem.

Gao WQ, Hatten ME. 1993. Neuronal differentiation rescued by implantation of Weaver granule cell precursors into wild-type cerebellar cortex. Science 260: 367-369.

Garrido JJ, Simon D, Varea O, Wandosell F. 2007. GSK3 $\alpha$ and GSK3 $\beta$ are necessary for axon formation. FEBS Lett 581: 1579-1586.

Gartner A, Huang X, Hall A. 2006. Neuronal polarity is regulated by glycogen synthase kinase- 3 (GSK-3 $\beta$ ) independently of Akt/PKB serine phosphorylation. J Cell Sci 119: 3927-3934.

Gertler F. 2010. The growth cone machine: Biochemical regulators of the cytoskeleton. Cold Spring Harb Perspect Biol doi: 10.1101/cshperspect.a001800.

Goldberg JL, Espinosa JS, Xu Y, Davidson N, Kovacs GT, Barres BA. 2002. Retinal ganglion cells do not extend axons by default: Promotion by neurotrophic signaling and electrical activity. Neuron 33: 689-702.

Goldstein B, Macara IG. 2007. The PAR proteins: Fundamental players in animal cell polarization. Dev Cell 13: 609-622.

Gomez TM, Spitzer NC. 1999. In vivo regulation of axon extension and pathfinding by growth-cone calcium transients. Nature 397: 350-355.

Gomez TM, Snow DM, Letourneau PC. 1995. Characterization of spontaneous calcium transients in nerve growth cones and their effect on growth cone migration. Neuron 14: $1233-1246$.

Gonzalez-Billault C, Jimenez-Mateos EM, Caceres A, Diaz-Nido J, Wandosell F, Avila J. 2004. Microtubule-associated protein 1B function during normal development, regeneration, and pathological conditions in the nervous system. J Neurobiol 58: 48-59. 


\section{F. Polleux and W. Snider}

Goslin K, Banker G. 1989. Experimental observations on the development of polarity by hippocampal neurons in culture. J Cell Biol 108: 1507-1516.

Graef IA, Wang F, Charron F, Chen L, Neilson J, TessierLavigne M, Crabtree GR. 2003. Neurotrophins and netrins require calcineurin/NFAT signaling to stimulate outgrowth of embryonic axons. Cell 113: 657-670.

Hall A, Lalli G. 2010. Rho and Ras GTPases in axon growth, guidance, and branching. Cold Spring Harb Perspect Biol 2: a001818.

Hall AC, Lucas FR, Salinas PC. 2000. Axonal remodeling and synaptic differentiation in the cerebellum is regulated by WNT-7a signaling. Cell 100: 525-535.

Hand R, Bortone D, Mattar P, Nguyen L, Heng JI, Guerrier S, Boutt E, Peters E, Barnes AP, Parras C et al. 2005. Phosphorylation of Neurogenin2 specifies the migration properties and the dendritic morphology of pyramidal neurons in the neocortex. Neuron 48: 45-62.

Hatanaka Y, Murakami F. 2002. In vitro analysis of the origin, migratory behavior, and maturation of cortical pyramidal cells. J Comp Neurol 454: 1-14.

Hengst U, Jaffrey SR. 2007. Function and translational regulation of mRNA in developing axons. Semin Cell Dev Biol 18: 209-215.

Hengst U, Deglincerti A, Kim HJ, Jeon NL, Jaffrey SR. 2009. Axonal elongation triggered by stimulus-induced local translation of a polarity complex protein. Nat Cell Biol 11: 1024-1030.

Hilliard MA, Bargmann CI. 2006. Wnt signals and frizzled activity orient anterior-posterior axon outgrowth in C. elegans. Dev Cell 10:379-390.

Hinds JW, Hinds PL. 1978. Early development of amacrine cells in the mouse retina: An electron microscopic, serial section analysis. J Comp Neurol 179: 277-300.

Honma Y, Araki T, Gianino S, Bruce A, Heuckeroth R, Johnson E, Milbrandt J. 2002. Artemin is a vascular-derived neurotropic factor for developing sympathetic neurons. Neuron 35: 267-282.

Horiuchi D, Collins CA, Bhat P, Barkus RV, Diantonio A, Saxton WM. 2007. Control of a kinesin-cargo linkage mechanism by JNK pathway kinases. Curr Biol 17: 1313-1317.

Ikeuchi Y, Stegmuller J, Netherton S, Huynh MA, Masu M, Frank D, Bonni S, Bonni A. 2009. A SnoN-Ccd1 pathway promotes axonal morphogenesis in the mammalian brain. J Neurosci 29: 4312-4321.

Illenberger S, Drewes G, Trinczek B, Biernat J, Meyer HE, Olmsted JB, Mandelkow EM, Mandelkow E. 1996. Phosphorylation of microtubule-associated proteins MAP2 and MAP4 by the protein kinase p110mark. Phosphorylation sites and regulation of microtubule dynamics. J Biol Chem 271: 10834-10843.

Inagaki N, Chihara K, Arimura N, Menager C, Kawano Y, Matsuo N, Nishimura T, Amano M, Kaibuchi K. 2001 CRMP-2 induces axons in cultured hippocampal neurons. Nat Neurosci 4: 781-782.

Jiang H, Guo W, Liang X, Rao Y. 2005. Both the establishment and the maintenance of neuronal polarity require active mechanisms: Critical roles of GSK-3 $\beta$ and its upstream regulators. Cell 120: 123-135.
Job C, Eberwine J. 2001. Localization and translation of mRNA in dendrites and axons. Nat Rev Neurosci 2: 889-898.

Joberty G, Petersen C, Gao L, Macara IG. 2000. The cellpolarity protein Par6 links Par3 and atypical protein kinase C to Cdc42. Nat Cell Biol 2: 531-539.

Jossin Y, Goffinet AM. 2007. Reelin signals through phosphatidylinositol 3-kinase and Akt to control cortical development and through mTor to regulate dendritic growth. Mol Cell Biol 27: 7113-7124.

Kemphues KJ, Priess JR, Morton DG, Cheng NS. 1988 Identification of genes required for cytoplasmic localization in early C. elegans embryos. Cell 52: 311-320.

Kim WY, Wang X, Wu Y, Doble BW, Patel S, Woodgett JR, Snider WD. 2009. GSK-3 is a master regulator of neural progenitor homeostasis. Nat Neurosci 12: 1390-1397.

Kim WY, Zhou FQ, Zhou J, Yokota Y, Wang YM, Yoshimura T, Kaibuchi K, Woodgett JR, Anton ES, Snider WD. 2006. Essential roles for GSK-3s and GSK-3-primed substrates in neurotrophin-induced and hippocampal axon growth. Neuron 52: 981-996.

Kirschner M, Mitchison T. 1986. Beyond self-assembly: From microtubules to morphogenesis. Cell 45: 329-342.

Kishi M, Pan YA, Crump JG, Sanes JR. 2005. Mammalian $\mathrm{SAD}$ kinases are required for neuronal polarization. Science 307: 929-932.

Klimaschewski L, Hausott B, Ingorokva S, Pfaller K. 2006. Constitutively expressed catalytic proteasomal subunits are up-regulated during neuronal differentiation and required for axon initiation, elongation and maintenance. J Neurochem 96: 1708-1717.

Komuro H, Yacubova E, Rakic P. 2001. Mode and tempo of tangential cell migration in the cerebellar external granular layer. J Neurosci 21: 527-540.

Konishi Y, Stegmuller J, Matsuda T, Bonni S, Bonni A. 2004. Cdh1-APC controls axonal growth and patterning in the mammalian brain. Science 303: 1026-1030.

Krylova O, Herreros J, Cleverley KE, Ehler E, Henriquez JP, Hughes SM, Salinas PC. 2002. WNT-3, expressed by motoneurons, regulates terminal arborization of neurotrophin-3-responsive spinal sensory neurons. Neuron 35: $1043-1056$.

Kuan CY, Yang DD, Samanta Roy DR, Davis RJ, Rakic P, Flavell RA. 1999. The Jnk1 and Jnk2 protein kinases are required for regional specific apoptosis during early brain development. Neuron 22: 667-676.

Kuruvilla R, Zweifel LS, Glebova NO, Lonze BE, Valdez G, Ye H, Ginty DD. 2004. A neurotrophin signaling cascade coordinates sympathetic neuron development through differential control of TrkA trafficking and retrograde signaling. Cell 118: 243-255.

Kyriakis JM, Avruch J. 1990. pp54 microtubule-associated protein 2 kinase. A novel serine/threonine protein kinase regulated by phosphorylation and stimulated by poly-L-lysine. J Biol Chem 265: 17355-17363.

Lentz SI, Knudson CM, Korsmeyer SJ, Snider WD. 1999. Neurotrophins support the development of diverse sensory axon morphologies. J Neurosci 19: 1038-1048.

Leppa S, Saffrich R, Ansorge W, Bohmann D. 1998. Differential regulation of c-Jun by ERK and JNK during PC12 cell differentiation. Embo J 17: 4404-4413. 
Lewcock JW, Genoud N, Lettieri K, Pfaff SL. 2007. The ubiquitin ligase $\mathrm{Phr} 1$ regulates axon outgrowth through modulation of microtubule dynamics. Neuron 56: 604-620.

Lin AC, Holt CE. 2008. Function and regulation of local axonal translation. Curr Opin Neurobiol 18: 60-68.

Lin D, Edwards AS, Fawcett JP, Mbamalu G, Scott JD, Pawson T. 2000. A mammalian PAR-3-PAR-6 complex implicated in $\mathrm{Cdc} 42 / \mathrm{Racl}$ and aPKC signalling and cell polarity. Nat Cell Biol 2: $540-547$.

Lizcano JM, Goransson O, Toth R, Deak M, Morrice NA, Boudeau J, Hawley SA, Udd L, Makela TP, Hardie DG et al. 2004. LKB1 is a master kinase that activates 13 kinases of the AMPK subfamily, including MARK/PAR-1. Embo J 23: 833-843.

Lonze BE, Riccio A, Cohen S, Ginty DD. 2002. Apoptosis, axonal growth defects, and degeneration of peripheral neurons in mice lacking CREB. Neuron 34: 371-385.

Luo W, Wickramasinghe SR, Savitt JM, Griffin JW, Dawson TM, Ginty DD. 2007. A hierarchical NGF signaling cascade controls Ret-dependent and Ret-independent events during development of nonpeptidergic DRG neurons. Neuron 54: 739-754.

Lyuksyutova AI, Lu CC, Milanesio N, King LA, Guo N, Wang Y, Nathans J, Tessier-Lavigne M, Zou Y. 2003. Anterior-posterior guidance of commissural axons by Wnt-frizzled signaling. Science 302: 1984-1988.

Ma L, Harada T, Harada C, Romero M, Hebert JM, McConnell SK, Parada LF. 2002. Neurotrophin-3 is required for appropriate establishment of thalamocortical connections. Neuron 36: 623-634.

Maccario H, Perera NM, Davidson L, Downes CP, Leslie NR. 2007. PTEN is destabilized by phosphorylation on Thr366. Biochem J 405: 439-444.

Manabe N, Hirai S, Imai F, Nakanishi H, Takai Y, Ohno S. 2002. Association of ASIP/mPAR-3 with adherens junctions of mouse neuroepithelial cells. Dev Dyn 225: 61-69.

Markus A, Zhong J, Snider WD. 2002. Raf and akt mediate distinct aspects of sensory axon growth. Neuron 35: $65-76$.

Matenia D, Mandelkow EM. 2009. The tau of MARK: A polarized view of the cytoskeleton. Trends Biochem Sci 34: $332-342$.

Menager C, Arimura N, Fukata Y, Kaibuchi K. 2004. PIP3 is involved in neuronal polarization and axon formation. J Neurochem 89: 109-118.

Morgan JL, Dhingra A, Vardi N, Wong RO. 2006. Axons and dendrites originate from neuroepithelial-like processes of retinal bipolar cells. Nat Neurosci 9: 85-92.

Nakata K, Abrams B, Grill B, Goncharov A, Huang X, Chisholm AD, Jin Y. 2005. Regulation of a DLK-1 and p38 MAP kinase pathway by the ubiquitin ligase RPM1 is required for presynaptic development. Cell 120: 407-420.

Neidhart S, Antonsson B, Gillieron C, Vilbois F, Grenningloh G, Arkinstall S. 2001. c-Jun N-terminal kinase-3 (JNK3)/stress-activated protein kinase-beta (SAPK $\beta$ ) binds and phosphorylates the neuronal microtubule regulator SCG10. FEBS Lett 508: 259-264.

Newbern J, Taylor A, Robinson M, Lively MO, Milligan CE. 2007. c-Jun $\mathrm{N}$-terminal kinase signaling regulates events associated with both health and degeneration in motoneurons. Neuroscience 147: 680-692.

Nishimura T, Kato K, Yamaguchi T, Fukata Y, Ohno S, Kaibuchi K. 2004. Role of the PAR-3-KIF3 complex in the establishment of neuronal polarity. Nat Cell Biol 6: 328-334.

Nishimura T, Yamaguchi T, Kato K, Yoshizawa M, Nabeshima Y, Ohno S, Hoshino M, Kaibuchi K. 2005. PAR-6-PAR-3 mediates Cdc42-induced Rac activation through the Rac GEFs STEF/Tiam1. Nat Cell Biol 7: 270-277.

Noctor SC, Martinez-Cerdeno V, Ivic L, Kriegstein AR. 2004. Cortical neurons arise in symmetric and asymmetric division zones and migrate through specific phases. Nat Neurosci 7: 136-144.

O'Connor R, Tessier-Lavigne M. 1999. Identification of maxillary factor, a maxillary process-derived chemoattractant for developing trigeminal sensory axons. Neuron 24: $165-178$.

Oliva AA Jr, Atkins CM, Copenagle L, Banker GA. 2006. Activated c-Jun $\mathrm{N}$-terminal kinase is required for axon formation. J Neurosci 26: 9462-9470.

Otto IM, Raabe T, Rennefahrt UE, Bork P, Rapp UR, Kerkhoff E. 2000. The p150-Spir protein provides a link between c-Jun N-terminal kinase function and actin reorganization. Curr Biol 10: 345-348.

Ozdamar B, Bose R, Barrios-Rodiles M, Wang HR, Zhang Y, Wrana JL. 2005. Regulation of the polarity protein Par6 by TGFbeta receptors controls epithelial cell plasticity. Science 307: 1603-1609.

Ozdinler PH, Macklis JD. 2006. IGF-I specifically enhances axon outgrowth of corticospinal motor neurons. Nat Neurosci 9: 1371-1381.

Pan CL, Baum PD, Gu M, Jorgensen EM, Clark SG, Garriga G. 2008. C. elegans AP-2 and retromer control Wnt signaling by regulating mig-14/Wntless. Dev Cell 14: $132-139$.

Park KK, Liu K, Hu Y, Smith PD, Wang C, Cai B, Xu B, Connolly L, Kramvis I, Sahin M et al. 2008. Promoting axon regeneration in the adult CNS by modulation of the PTEN/mTOR pathway. Science 322: 963-966.

Patel TD, Jackman A, Rice FL, Kucera J, Snider WD. 2000. Development of sensory neurons in the absence of NGF/TrkA signaling in vivo. Neuron 25: 345-357.

Patel TD, Kramer I, Kucera J, Niederkofler V, Jessell TM, Arber S, Snider WD. 2003. Peripheral NT3 signaling is required for ETS protein expression and central patterning of proprioceptive sensory afferents. Neuron 38: 403-416.

Plant PJ, Fawcett JP, Lin DC, Holdorf AD, Binns K, Kulkarni S, Pawson T. 2003. A polarity complex of mPar-6 and atypical PKC binds, phosphorylates and regulates mammalian Lgl. Nat Cell Biol 5: 301-308.

Polleux F, Ince-Dunn G, Ghosh A. 2007. Transcriptional regulation of vertebrate axon guidance and synapse formation. Nat Rev Neurosci 8: 331-340.

Polleux F, Giger RJ, Ginty DD, Kolodkin AL, Ghosh A. 1998. Patterning of cortical efferent projections by semaphorin-neuropilin interactions. Science 282: 1904-1906.

Polleux F, Whitford KL, Dijkhuizen PA, Vitalis T, Ghosh A. 2002. Control of cortical interneuron migration by 
F. Polleux and W. Snider

neurotrophins and PI3-kinase signaling. Development 129: 3147-3160.

Prasad BC, Clark SG. 2006. Wnt signaling establishes anteroposterior neuronal polarity and requires retromer in C. elegans. Development 133: 1757-1766.

Purro SA, Ciani L, Hoyos-Flight M, Stamatakou E, Siomou E, Salinas PC. 2008. Wnt regulates axon behavior through changes in microtubule growth directionality: A new role for adenomatous polyposis coli. J Neurosci 28: 8644-8654.

Qiu RG, Abo A, Steven Martin G. 2000. A human homolog of the C. elegans polarity determinant Par-6 links Rac and $\mathrm{Cdc42}$ to $\mathrm{PKC} \zeta$ signaling and cell transformation. Curr Biol 10: 697-707.

Quinn CC, Wadsworth WG. 2008. Axon guidance: Asymmetric signaling orients polarized outgrowth. Trends Cell Biol 18: 597-603.

Quinn CC, Pfeil DS, Wadsworth WG. 2008. CED-10/Rac1 mediates axon guidance by regulating the asymmetric distribution of MIG-10/lamellipodin. Curr Biol 18: 808-813.

Rakic P. 1971. Neuron-glia relationship during granule cell migration in developing cerebellar cortex. A Golgi and electronmicroscopic study in Macacus Rhesus. J Comp Neurol 141: 283-312.

Rakic P. 1972. Mode of cell migration to the superficial layers of fetal monkey neocortex. J Comp Neurol 145: 61-83.

Reichardt LF. 2006. Neurotrophin-regulated signalling pathways. Philos Trans R Soc Lond B Biol Sci 361: 1545-1564.

Rolls MM, Doe CQ. 2004. Baz, Par-6 and aPKC are not required for axon or dendrite specification in Drosophila. Nat Neurosci 7: 1293-1295.

Rosso SB, Sussman D, Wynshaw-Boris A, Salinas PC. 2005. Wnt signaling through Dishevelled, Rac and JNK regulates dendritic development. Nat Neurosci 8: 34-42.

Sabapathy K, Jochum W, Hochedlinger K, Chang L, Karin M, Wagner EF. 1999. Defective neural tube morphogenesis and altered apoptosis in the absence of both JNK1 and JNK2. Mech Dev 89: 115-124.

Saito T, Nakatsuji N. 2001. Efficient gene transfer into the embryonic mouse brain using in vivo electroporation. Dev Biol 240: 237-246.

Salinas PC, Zou Y. 2008. Wnt signaling in neural circuit assembly. Annu Rev Neurosci 31: 339-358.

Samuels IS, Karlo JC, Faruzzi AN, Pickering K, Herrup K, Sweatt JD, Saitta SC, Landreth GE. 2008. Deletion of ERK2 mitogen-activated protein kinase identifies its key roles in cortical neurogenesis and cognitive function. J Neurosci 28: 6983-6995.

Sapkota GP, Kieloch A, Lizcano JM, Lain S, Arthur JS, Williams MR, Morrice N, Deak M, Alessi DR. 2001. Phosphorylation of the protein kinase mutated in PeutzJeghers cancer syndrome, LKB1/STK11, at Ser431 by p90(RSK) and cAMP-dependent protein kinase, but not its farnesylation at Cys(433), is essential for LKB1 to suppress cell vrowth. J Biol Chem 276: 19469-19482.

Schober M, Schaefer M, Knoblich JA. 1999. Bazooka recruits Inscuteable to orient asymmetric cell divisions in Drosophila neuroblasts. Nature 402: 548-551.

Schwamborn JC, Khazaei MR, Puschel AW. 2007a. The interaction of mPar3 with the ubiquitin ligase Smurf2 is required for the establishment of neuronal polarity. J Biol Chem 282: 35259-35268.

Schwamborn JC, Muller M, Becker AH, Puschel AW. 2007b. Ubiquitination of the GTPase Rap1B by the ubiquitin ligase Smurf2 is required for the establishment of neuronal polarity. Embo J 26: 1410-1422.

Shelly M, Cancedda L, Heilshorn S, Sumbre G, Poo MM. 2007. LKB1/STRAD promotes axon initiation during neuronal polarization. Cell 129: 565-577.

Shi SH, Jan LY, Jan YN. 2003. Hippocampal neuronal polarity specified by spatially localized $\mathrm{mPar} 3 / \mathrm{mPar} 6$ and PI 3-kinase activity. Cell 112: 63-75.

Shi SH, Cheng T, Jan LY, Jan YN. 2004. APC and GSK-3 $\beta$ are involved in mPar3 targeting to the nascent axon and establishment of neuronal polarity. Curr Biol 14: 2025-2032.

Shoukimas GM, Hinds JW. 1978. The development of the cerebral cortex in the embryonic mouse: An electron microscopic serial section analysis. J Comp Neurol 179: 795-830.

Speese SD, Trotta N, Rodesch CK, Aravamudan B, Broadie K. 2003. The ubiquitin proteasome system acutely regulates presynaptic protein turnover and synaptic efficacy. Curr Biol 13: 899-910.

Sperber BR, Leight S, Goedert M, Lee VM. 1995. Glycogen synthase kinase-3 $\beta$ phosphorylates tau protein at multiple sites in intact cells. Neurosci Lett 197: 149-153.

Stack JH, Emr SD. 1994. Vps34p required for yeast vacuolar protein sorting is a multiple specificity kinase that exhibits both protein kinase and phosphatidylinositol-specific PI 3-kinase activities. J Biol Chem 269: 31552-31562.

Stagi M, Gorlovoy P, Larionov S, Takahashi K, Neumann H. 2006. Unloading kinesin transported cargoes from the tubulin track via the inflammatory c-Jun N-terminal kinase pathway. Faseb J 20: 2573-2575.

Stegmuller J, Huynh MA, Yuan Z, Konishi Y, Bonni A. 2008. TGF $\beta$-Smad2 signaling regulates the Cdh1-APC/SnoN pathway of axonal morphogenesis. J Neurosci 28: 1961-1969.

Stegmuller J, Konishi Y, Huynh MA, Yuan Z, Dibacco S, Bonni A. 2006. Cell-intrinsic regulation of axonal morphogenesis by the Cdh1-APC target SnoN. Neuron 50: 389-400.

Sutton MA, Schuman EM. 2006. Dendritic protein synthesis, synaptic plasticity, and memory. Cell 127: 49-58.

Tabata H, Nakajima K. 2001. Efficient in utero gene transfer system to the developing mouse brain using electroporation: Visualization of neuronal migration in the developing cortex. Neuroscience 103: 865-872.

Tararuk T, Ostman N, Li W, Bjorkblom B, Padzik A, Zdrojewska J, Hongisto V, Herdegen T, Konopka W, Courtney MJ et al. 2006. JNK1 phosphorylation of SCG10 determines microtubule dynamics and axodendritic length. J Cell Biol 173: 265-277.

Thornton TM, Pedraza-Alva G, Deng B, Wood CD, Aronshtam A, Clements JL, Sabio G, Davis RJ, Matthews DE, Doble B et al. 2008. Phosphorylation by p38 MAPK as an alternative pathway for GSK3beta inactivation. Science 320: $667-670$. 
Tucker KL, Meyer M, Barde YA. 2001. Neurotrophins are required for nerve growth during development. $\mathrm{Nat} \mathrm{Neu-}$ rosci 4: $29-37$.

von Stein W, Ramrath A, Grimm A, Muller-Borg M, Wodarz A. 2005. Direct association of Bazooka/PAR-3 with the lipid phosphatase PTEN reveals a link between the PAR/aPKC complex and phosphoinositide signaling. Development 132: 1675-1686.

Waetzig V, Herdegen T. 2003. The concerted signaling of ERK1/2 and JNKs is essential for PC12 cell neuritogenesis and converges at the level of target proteins. Mol Cell Neurosci 24: 238-249.

Wang KH, Brose K, Arnott D, Kidd T, Goodman CS, Henzel W, Tessier-Lavigne M. 1999. Biochemical purification of a mammalian slit protein as a positive regulator of sensory axon elongation and branching. Cell 96: 771-784.

Watts RJ, Schuldiner O, Perrino J, Larsen C, Luo L. 2004 Glia engulf degenerating axons during developmental axon pruning. Curr Biol 14: 678-684.

Wickramasinghe SR, Alvania RS, Ramanan N, Wood JN, Mandai K, Ginty DD. 2008. Serum response factor mediates NGF-dependent target innervation by embryonic DRG sensory neurons. Neuron 58: 532-545.

Witte H, Neukirchen D, Bradke F. 2008. Microtubule stabilization specifies initial neuronal polarization. J Cell Biol 180: 619-632.

Xiao J, Pradhan A, Liu Y. 2006. Functional role of JNK in neuritogenesis of PC12-N1 cells. Neurosci Lett 392: 231-234.

Yamauchi J, Miyamoto Y, Sanbe A, Tanoue A. 2006. JNK phosphorylation of paxillin, acting through the Racl and Cdc42 signaling cascade, mediates neurite extension in N1E-115 cells. Exp Cell Res 312: 2954-2961.

Yan D, Guo L, Wang Y. 2006. Requirement of dendritic Akt degradation by the ubiquitin-proteasome system for neuronal polarity. J Cell Biol 174: 415-424.
Yoshimura T, Arimura N, Kawano Y, Kawabata S, Wang S, Kaibuchi K. 2006. Ras regulates neuronal polarity via the PI3-kinase/Akt/GSK-3 $\beta /$ CRMP-2 pathway. Biochem Biophys Res Commun 340: 62-68.

Yoshimura T, Kawano Y, Arimura N, Kawabata S, Kikuchi A, Kaibuchi K. 2005. GSK-3beta regulates phosphorylation of CRMP-2 and neuronal polarity. Cell 120: 137-149.

Youle RJ, Strasser A. 2008. The BCL-2 protein family: Opposing activities that mediate cell death. Nat Rev Mol Cell Biol 9: 47-59.

Zhang H, Macara IG. 2008. The PAR-6 polarity protein regulates dendritic spine morphogenesis through p190 RhoGAP and the Rho GTPase. Dev Cell 14: 216-226.

Zhao Z, Wang Z, Gu Y, Feil R, Hofmann F, Ma L. 2009. Regulate axon branching by the cyclic GMP pathway via inhibition of glycogen synthase kinase 3 in dorsal root ganglion sensory neurons. J Neurosci 29: 1350-1360.

Zhong J, Li X, McNamee C, Chen AP, Baccarini M, Snider WD. 2007. Raf kinase signaling functions in sensory neuron differentiation and axon growth in vivo. Nat Neurosci 10: $598-607$.

Zhou FQ, Snider WD. 2006. Intracellular control of developmental and regenerative axon growth. Philos Trans $R$ Soc Lond B Biol Sci 361: 1575-1592.

Zhou P, Porcionatto M, Pilapil M, Chen Y, Choi Y, Tolias KF Bikoff JB, Hong EJ, Greenberg ME, Segal RA. 2007. Polarized signaling endosomes coordinate BDNF-induced chemotaxis of cerebellar precursors. Neuron 55: 53-68.

Zhou FQ, Zhou J, Dedhar S, Wu YH, Snider WD. 2004. NGF-induced axon growth is mediated by localized inactivation of GSK-3beta and functions of the microtubule plus end binding protein APC. Neuron 42: 897-912.

Zolessi FR, Poggi L, Wilkinson CJ, Chien CB, Harris WA. 2006. Polarization and orientation of retinal ganglion cells in vivo. Neural Develop 1: 2. 


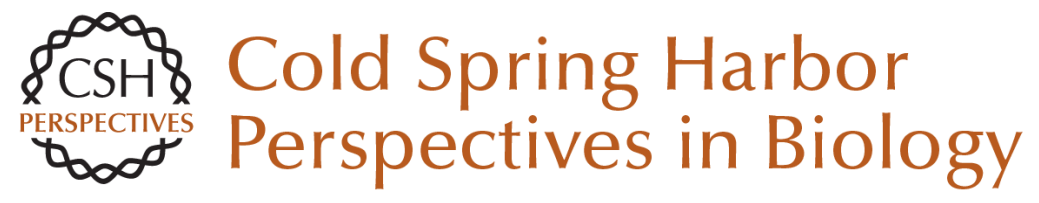

\section{Initiating and Growing an Axon}

F. Polleux and William Snider

Cold Spring Harb Perspect Biol 2010; doi: 10.1101/cshperspect.a001925

Subject Collection Neuronal Guidance

Mechanisms and Molecules of Neuronal Wiring: A

Primer

Alex L. Kolodkin and Marc Tessier-Lavigne

Guidance Molecules in Axon Pruning and Cell

Death

Pierre Vanderhaeghen and Hwai-Jong Cheng

Initiating and Growing an Axon

F. Polleux and William Snider

Navigating Intermediate Targets: The Nervous

System Midline

Barry J. Dickson and Yimin Zou

Cellular Strategies of Axonal Pathfinding Jonathan Raper and Carol Mason

Guidance Molecules in Axon Regeneration Roman J. Giger, Edmund R. Hollis II and Mark H. Tuszynski

Signaling from Axon Guidance Receptors Greg J. Bashaw and Rüdiger Klein

Visual Map Development: Bidirectional Signaling, Bifunctional Guidance Molecules, and Competition

David A. Feldheim and Dennis D. M. O'Leary
Wiring the Brain: The Biology of Neuronal Guidance Alain Chédotal and Linda J. Richards

Guidance Molecules in Synapse Formation and Plasticity Kang Shen and Christopher W. Cowan

The Growth Cone Cytoskeleton in Axon

Outgrowth and Guidance Erik W. Dent, Stephanie L. Gupton and Frank B. Gertler

Topographic Mapping--The Olfactory System Takeshi Imai, Hitoshi Sakano and Leslie B. Vosshall

Self-avoidance and Tiling: Mechanisms of

Dendrite and Axon Spacing Wesley B. Grueber and Alvaro Sagasti

Trafficking Guidance Receptors Bettina Winckler and Ira Mellman

Axon Guidance Molecules in Vascular Patterning Ralf H. Adams and Anne Eichmann

Human Genetic Disorders of Axon Guidance Elizabeth C. Engle

For additional articles in this collection, see http://cshperspectives.cshlp.org/cgi/collection/

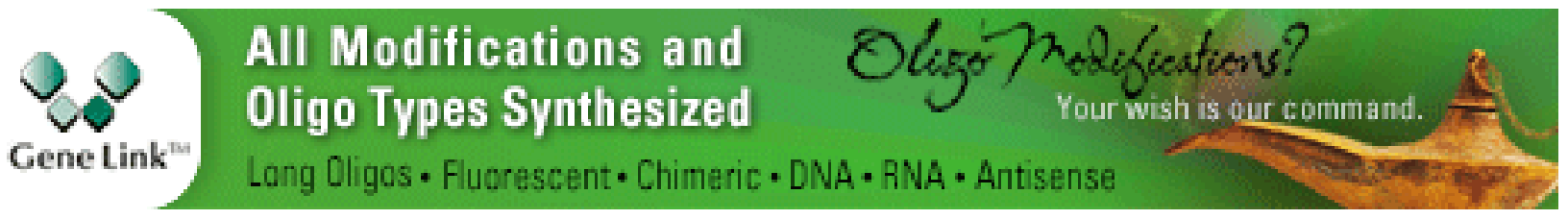

Copyright @ 2010 Cold Spring Harbor Laboratory Press; all rights reserved 